\title{
Caring Science within Islamic Contexts: A Literature Review
}

\author{
Suhartini Ismail ${ }^{1}$, Urai Hatthakit ${ }^{2}$, Tippamas Chinawong ${ }^{3}$
}

\begin{abstract}
Background: Caring is an essence of nursing and many studies enlighten about caring for various populations and settings. Caring science within Islamic contexts has gained more attention from nurses, especially in the area related to cultural and spiritual care.

Purpose: The aim of this study was to discuss the concepts of caring science within Islamic contexts.

Methods: We extracted 27 articles in both qualitative and quantitative studies, inthe English language, based on PRISMA (Preferred Reporting Items for Systematic Reviews and Meta-analyses) method. The date and years were limited from January 2008 to 2014 from several databases. Keywordswere 'caring science', 'Islamic caring', 'and Islamic Perspectives' and combined with words of 'Nursing', 'caring', and 'care'.

Result: There were 4 themes in caring within Islamic context: 1There were 6 themes in caring within Islamic context: 1) theoretical definition of caring; 2) foundation of caring; 3) comparison of caring theories; and 4) caring in Islamic culture; 5) caring practice in Islamic perspectives;and 6) caring outcomes

Conclusion: In Islamic nursing, caring is based on well-being improvement and healing, and concentration on all domains of nursing care and relationship between different dimensions of human (bio-psycho-social-spiritual dimensions). Within these contexts, a better understanding of the diverse conceptualizations of nursing is needed in order to ensure that nurses across all contexts can provide optimal care.
\end{abstract}

Keywords: Caring, Islamic contexts, Islamic caring.

1 PhD candidate, Faculty of Nursing, Prince of Songkla University, Hatyai, Thailand Lecturer in Emergency and Critical Care Nursing division, Adult Nursing Department School of Nursing, Faculty of Medicine of Diponegoro University, Semarang, Indonesia, Email: titinyayub@gmail.com

2 Assistant Professor, Faculty of Nursing, Prince of Songkla University, Hatyai, Thailand

3 Assistant Professor, Faculty of Nursing, Medical Nursing Department, Prince of Songkla University, Hatyai, Thailand 


\section{BACKGROUND}

Islam for Muslims is not only a religion but a complete way of life that advocates peace, mercy and forgiveness. Muslims tend to emphasize the relationship between Allah and the person, without intermediaries (Akhtar, 2002). The fundamental teaching of Islam is the belief in the oneness of Allah (Rassool, 2000). Muslims live their lifetime through the belief in and practice of the faith forAllah. Muslims use the six beliefs of Islam and the five pillars of Islam to guide them in practicing the faith in their life way. The six beliefs are: 1) belief in God, 2) belief in Angels, 3) belief in the Quran, 4) belief in the Prophets and Messengers of God, 5) belief in the Day of Judgment, 6) belief in $\mathrm{Al}$ Qadar (Divine predestination) (Ibrahim, 1999). Belief in Allah means believing firmly in His existence, Lordship and Divinity, and His names and attributes. Muslims believe in the existence of the angels and that they are honored creatures. The angels worship God alone, obey Him, and act only by His command. Among the angels is Gabriel, who brought down the Quran to Muhammad. Muslims believe in the prophets and messengers of God, starting with Adam, including Noah, Abraham, Ishmael, Isaac, Jacob, Moses, and Jesus (peace be upon them), but God's final messenger was revealed to the Prophet Muhammad. Muslims believe in the Day of Judgment when all people will be resurrected for God's judgment according to their beliefs and deeds. Muslims believe in Divine Predestination, but this belief does not mean that a Muslim does not have freewill. This means that Muslims can choose right or wrong and they are responsible for their choices (Islamic-Life Forums, 2009). For these reasons, the six beliefs of Islam are vital in order to have a sense of spirituality for Muslims.

Muslim also accept and follow the five pillars of Islam. Following the five pillars of Islam is an obligation or duty of every Muslim, and these help Muslims lead a disciplined life. The five pillars consist of: 1) the declaration of faith (Shahadah in Arabic), and Mohammad is His Prophet; 2) formal prayer/salat, 3) tithing/zakat, 4) fasting/saum, and 5) pilgrimage/hajj (Miklancie, 2007; Rassool, 2000). Religious status of Muslims will be reflected to the practice by these pillars and religious practice of a Muslim (Al-Lahim, 1999). Muslim patients believe that illness, suffering, and dying is a part of life and could be a test whereby Allah (God) checks the belief of the followers. During illness, Muslims are to seek God's help with patience and prayer, and increase the remembrance of God to obtain peace, ask for forgiveness, give more in charity, and read or listen to more of the Qur'an. God rewards those who bear their suffering with patience and faith in God's mercy. Therefore, seeking help from Allah and praying during the course of illness and difficulties is encouraged.

In performing prayer, Muslims can ask Allah to diminish the health problem and believe that Allah will grant it. Prayer is connected to change psychological well-being (Mebrouk, 2008). Fasting, tithing (Zakat), and pilgrimage (Hajj) are the ways a Muslim to clean the body and mind from sin and perhaps the God (Allah) will give the forgiveness, eventually a Muslim will get healthy and prosperous (Barolia \& Karmaliani, 2008; Rassool, 2000). The word zakat means purification and growth. Zakat provides guidelines for the provision of social justice, positive human behavior and equitable socio-economic system. Fasting is also beneficial for health. Fasting is regarded spiritually as a method of self-purification. For Muslims, pilgrimage to Mecca 
is aimed to purify the bodies and mind from the sins, and gain their spirit (Rassool, 2000).

Caring is a natural outcome of having a love for Allah and the Prophet. Caring in Islam means the will to be responsible, sensitive, concerned with the motivation, and commitment to acting in the right order to achieve perfection. In Islam, caring is expressed by three levels: Intention, thought, and action. Intention and thought, is understanding of what, when, who to care for and why. The action level is the how and what is related to knowledge, skills, and resources are embedded with the process and outcome of caring (Rassool, 2000). Therefore, we specified the objective of the literature review was to provide the concepts of caring science within Islamic contexts.

\section{METHODS}

There were 130 articles retrieved based on PRISMA and other data bases namely Medline, CINAHL, PubMed, Science Direct, and Springer between January 2008 and 2014. The inclusion criteria were published in English, quantitative and qualitative study, full research article, and published/unpublished thesis. The keywords used in retrieving: 'caring science', 'Islamic caring', 'and Islamic Perspectives' and combined with words of 'nursing', 'caring', and 'care'. There were 70 articlesscreened and 30 articles excluded. Excluded numerous articles were because after reading those articles, it did not synchronize with Islamic based caring and nursing science.

Figure 1. Flow of information articles through the different phases of a literature review

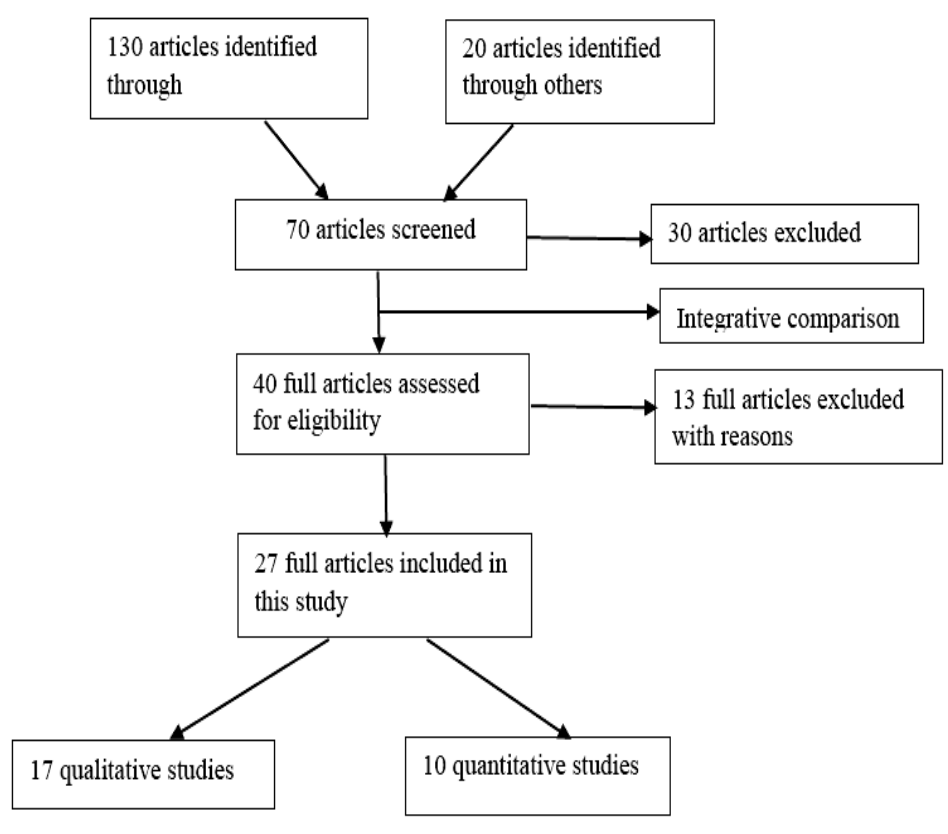

\section{RESULT}

The twenty seven full articles that include in this study after the thematic analysis and integrative comparison of those articles were concluded. There were 6 themes in caring within Islamic context: 1) theoretical definition of caring; 2) foundation of caring; 
3) comparison of caring theories; and 4) caring in Islamic culture; 5) caring practice in Islamic perspectives; and 6) caring outcomes.

\section{Theoretical Definition of Caring}

Caring has been a focus of nursing. Several nurse theorists emphasized its centrality to their work. Every human being is in need of and capable of caring (Boykin \& Schoenhofer, 2001). The essence of human caring is shown through intention, empathy, authenticity, compassion, authentic presence, availability, and communication (Ray, 2010). Some nurse theorists and theoretical definition of caring, we resumed in the table 1.

Table 1. Nurse Theorist and Theoretical Definition of Caring

\begin{tabular}{|c|c|}
\hline Nurse theorist & Theoretical definition \\
\hline Watson (2008) & $\begin{array}{l}\text { A value and attitude that has to become a will, an intention, or a } \\
\text { commitment, that manifest itself in concrete acts (p.32). }\end{array}$ \\
\hline $\begin{array}{l}\text { Boykin and Schoenhofer } \\
\text { (2001) }\end{array}$ & $\begin{array}{l}\text { Caring is the intentional and authentic presence of the nurse with } \\
\text { another who is recognized as person living caring and growing in } \\
\text { caring. }\end{array}$ \\
\hline $\begin{array}{l}\text { Roach (1984) as cited in } \\
\text { Ray (2010) }\end{array}$ & $\begin{array}{l}\text { Roach defined caring as compassion, commitment, conscience, } \\
\text { confidence, competence, and comportment. }\end{array}$ \\
\hline Mayeroff (1971) & The ingredients of caring focused on helping others grow. \\
\hline Ray (2005) & $\begin{array}{l}\text { Caring as the unifying focus of nursing. Interconnected of } \\
\text { humanistic and spiritual caring and the }\end{array}$ \\
\hline Locsin $(2005)$ & Viewed caring in nursing technology competencies. \\
\hline
\end{tabular}

\section{Foundation of Caring}

Caring theory

Over the decade, the practical meaning of caring has been extended to large numbers of research papers. Nurse scholars also have increasingly recognized the caring science as a discipline that requires specific methods of inquiry. For better understanding caring according to five well-known theorists were compared and discussed: Leininger's theory of culture care, Watson's theory of human care, Roach's conceptualization of caring, and Boykin \& Schoenhofers's theory of nursing as caring, 
Table 2. Core concepts of caring

\begin{tabular}{|c|c|c|c|c|}
\hline & Leininger $^{(a)}$ & Watson ${ }^{\text {(a) }}$ & Roach $^{\text {(a) }}$ & $\begin{array}{l}\text { Boykin\& } \\
\text { Schoenfoer (a) }\end{array}$ \\
\hline $\begin{array}{l}\text { Origin of } \\
\text { theory }\end{array}$ & Anthropology & $\begin{array}{l}\text { Human science and } \\
\text { metaphysics }\end{array}$ & $\begin{array}{l}\text { Philosophy and } \\
\text { theology }\end{array}$ & $\begin{array}{l}\text { Philosophy and } \\
\text { human science }\end{array}$ \\
\hline $\begin{array}{l}\text { Description } \\
\text { of caring }\end{array}$ & $\begin{array}{l}\text { Caring refers to } \\
\text { actions and activities } \\
\text { directed toward } \\
\text { assisting, supporting, } \\
\text { or enabling another } \\
\text { individual or group } \\
\text { with evidence or } \\
\text { anticipated needs to } \\
\text { ameliorate or } \\
\text { improve a human } \\
\text { condition or life way, } \\
\text { or face death. }\end{array}$ & $\begin{array}{l}\text { A value and an } \\
\text { attitude that has to } \\
\text { become a will, an } \\
\text { intention, or a } \\
\text { commitment, that } \\
\text { manifest itself in } \\
\text { concrete acts }\end{array}$ & $\begin{array}{l}\text { Caring is the human } \\
\text { mode of being }\end{array}$ & $\begin{array}{l}\text { Caring is the } \\
\text { intentional and } \\
\text { authentic presence } \\
\text { of the nurse with } \\
\text { another who is } \\
\text { recognized as a } \\
\text { person living } \\
\text { caring and growing } \\
\text { in caring. }\end{array}$ \\
\hline $\begin{array}{l}\text { Description } \\
\text { of nursing }\end{array}$ & $\begin{array}{l}\text { Nursing refers to a } \\
\text { learned humanistic } \\
\text { and scientific } \\
\text { profession and } \\
\text { discipline which is } \\
\text { focused on human } \\
\text { care phenomena and } \\
\text { activities. }\end{array}$ & $\begin{array}{l}\text { A human science of } \\
\text { persons and human } \\
\text { health illness } \\
\text { experience that are } \\
\text { mediated by } \\
\text { professional, } \\
\text { personal, scientific, } \\
\text { aesthetic, and } \\
\text { ethical human care } \\
\text { transactions }\end{array}$ & $\begin{array}{l}\text { Nursing is the } \\
\text { professionalization } \\
\text { of human caring, } \\
\text { through the } \\
\text { affirmation that } \\
\text { caring is the human } \\
\text { mode of being and } \\
\text { through the } \\
\text { development of the } \\
\text { capacity to care } \\
\text { through acquisition } \\
\text { of skills, cognitive, } \\
\text { affective, technical, } \\
\text { and administrative }\end{array}$ & $\begin{array}{l}\text { Nursing as caring } \\
\text { involves the } \\
\text { nurturing of } \\
\text { persons living } \\
\text { caring and growing } \\
\text { in caring }\end{array}$ \\
\hline $\begin{array}{l}\text { Key } \\
\text { concepts }\end{array}$ & $\begin{array}{l}\text { Caring: culture; } \\
\text { culture care diversity } \\
\text { and universality }\end{array}$ & $\begin{array}{l}\text { Transpersonal } \\
\text { caring and the } 10 \\
\text { carative factors }\end{array}$ & $\begin{array}{l}\text { The six Cs of caring } \\
\text { (Compassion, } \\
\text { Competence, } \\
\text { Confidence, } \\
\text { Conscience, } \\
\text { Commitment, } \\
\text { Comportment) }\end{array}$ & $\begin{array}{l}\text { Personhood \& the } \\
\text { nursing situation }\end{array}$ \\
\hline $\begin{array}{l}\text { Goal/ } \\
\text { Outcome }\end{array}$ & $\begin{array}{l}\text { To improve and } \\
\text { provide care which is } \\
\text { culturally acceptable } \\
\text { and is beneficial and } \\
\text { useful to the client } \\
\text { and family }\end{array}$ & $\begin{array}{l}\text { To protect, enhance } \\
\text { and preserve } \\
\text { humanity by helping } \\
\text { a person find } \\
\text { meaning in illness, } \\
\text { suffering, pain and } \\
\text { existence }\end{array}$ & $\begin{array}{l}\text { Roach does not } \\
\text { clearly state a goal } \\
\text { or outcome }\end{array}$ & $\begin{array}{l}\text { Enhancement of } \\
\text { personhood }\end{array}$ \\
\hline $\begin{array}{l}\text { Scope of } \\
\text { theory }\end{array}$ & Middle range theory & Middle range theory & Grand theory & Grand theory \\
\hline
\end{tabular}


(a) From "Caring: Theoretical Perspectives of Relevance to Nursing," by T.V McCance, H.P. McKenna, \& J. R. P. Boore, 1999. Journal of Advanced Nursing, 30(6), P 1390. (b) From "Caring in Nursing from an Islamic Perspective: A Grounded Theory Approach,” Barolia \& Karmaliani, 2008. International Journal of Human Caring, 13(1), 55-63

\section{Comparison of caring theories}

\section{Leininger's Theory of Culture Care}

Leininger (1988) views caring as universal phenomena, but the expression and pattern of it vary across culture. For the patient to benefit from caring, caring patterns must be placed within their cultural context to be effective (Beeby, 2000). To provide therapeutic nursing care, nurses should have knowledge of caring values, beliefs, and practices of the patients (Leininger, 1988). She suggested nurses rely on technology and psychophysiological actions in order to assist their patients. Whilst, she acknowledges the influences of a technological approach to care which may reduce patients in a mechanistic way, she believes that by ascertaining the cultural influences on caring in each nurse can begin to provide meaningful care for the patient (Leininger, 1988). Leininger also acknowledged that caring has a biophysics dimension (Beeby, 2000).

\section{Watson's Theory of Human Care}

Watson (2008) evolved a theory of nursing which center around caring in the interpersonal relationship between a nurse and a patient. Watson views nursing as the science of caring, involving true concern for another individual and the desire to assist the other individual to health. According to Watson (2008), a relationship of interdependence between the nurse and the patient, resting on an assumption that patients are always able to express themselves. It implied that, for those using this theory, caring does not exist in areas where communication may be compromised, like in an intensive care environment.

Watson (2008) believes that a caring environment offers the development of potential while allowing the patient to choose the best action for him or herself at a given point in time. The multi-disciplinary team often makes decisions in the best interest of the patient, without truly knowing the interest of the particular patient being considered; thus paternalism may dominate autonomy (Beeby, 2000). Within Watson's theory (2008) there was a high emphasis on subjective experience for both the nurse and the patient, promoting personal growth and self-actualization for both parties. This might suggest that nursing in the highly specialized environment such as ICU, may have little caring value when the interpersonal relationship cannot fully realize by knowing the patient (Beeby, 2000).

\section{Roach's Conceptualization of Caring}

Roach conceptualizes that caring as the human mode of being. She claims that the essential characteristics of nursing as a helping discipline (Roach 1984, p.12, as cited in McCance et al, 1999). In 1992, the main concepts of Roach's theory were 5 Cs as attributes of caring. First is compassion, a way of living born out of an awareness of one's relationship to all living creatures. Second is competence, the state of having knowledge, judgement, skill, energy, experience and motivation required to respond adequately to the demands of one's professional ability. Third is confidence, the quality which fosters trusting relationships. Fourth is conscience, a state of moral awareness. Fifth is commitment, a complex affective characterized by convergence between one's 
desires and one's obligations, and by a deliberate choice to act in accordance with them (Roach, 2013). In 2002, she added her concepts with 'comportment' (6 Cs). Comportment is presenting oneself as someone who respects others and demands respect (Roach, 2013).

\section{Boykin\& Schoenhofers's Theory of Nursing as Caring}

The idea Boykin and Schoenhofers' theory illustrates that caring as a necessary feature and expresses human being (Boykin \& Schoenhofer, 2001). They view nursing the response to unique human need to be recognized as a caring person and to be supported in caring (McCance et al., 1999). Boykin and Schoenhofers' theory take a similar viewpoint to Roach's theory, they argue that despite caring is not unique to nursing, and it is uniquely expressed in nursing (McCance et al., 1999, p. 1391). According to Boykin and Schoenhofers (2001), the nursing situation develops when both persons present themselves as wanting to offer and receive professional nursing service.

We also noted the similarities of caring theories and theory of caring in Islamic perspective. The similarities of those existing theories, we discussed as follows:

a. Based on theory of caring both Leininger (1988) and Watson (2008), value the humanistic, sciences, and debating caring as a part of nursing which had therapeutic benefit and distinct and complementary to that of curing.

b. The caring dimension identified from Barolia and Karmaliani's theory is similar to the one in the human sciences and the metaphysical dimension (philosophy of being and knowing) of Watson's theory. For example, the concepts of hope, relationship, positive and negative responses, transpersonal teaching/learning in the form of role modeling, and spiritual forces are alike in both the theories

c. In Roach's conceptualization of caring had emerged in the Barolia and Karmaliani's theory. Roach explained that compassion and conscience in his theory. Based on Barolia and Karmaliani compassion and conscience were reflected in the spiritual dimension. Meanwhile, competence and confidence Roach's theory have been shown in the intellectual dimension of Barolia and Karmaliani's theory.

d. In Boykin \& Schoenfoer's theory, the unique human focus was signified in all the dimensions of caring in nursing from an Islamic perspective (physical, ethical, moral and ethical, spiritual, and intellectual dimensions).

As a Western country may develop the theory in terms of Christian religion, however, the caring from an Islamic perspective is like any other religion or non-religious perspective. It is because of the theories are based on the universal values of nursing. Like in Christ, in Islam the body is respected and is considered important because it carries the soul (Barolia \& Karmaliani, 2008).

\section{Caring in Islamic Culture}

Although, Barolia and Karmaliani's theory have some similarities with four existing caring theories, it is noted that caring in nursing an Islamic perspective does not high point the concept of culture proposed by Leininger. Nevertheless, it can be assumed that because 'culture is embedded in religion and cultural differences therefore have not been identified as a major concern by participants while exploring caring in nursing 
from an Islamic Perspective (Barolia \& Karmaliani, 2008). The principalpractices of caring from an Islamic perspective are based on the divine revelation that is permanent, and the one who practices caring receives many blessings. The Prophet shows how Allah expects human beings to act by caring for other people (Rassool, 2000). Muslim believe that religious teachings bear on all aspects of life, and they strive to keep God at the center of their consciousness, intentions, and actions such as the five pillars of Islam (Power, 2007; Stefan, 2010).

Barolia and Karmaliani (2008) had develop a theory of caring in nursing from an Islamic perspective: an interactive model. According to this theory, the nurse succeeds in caring behaviors and caring actions if she/he is sustaining a balance among all the five dimensions. Failure to maintain the balance results in disequilibrium or uncaring gestures. They justified that balancing the five dimensions of the human personality is essential for providing nursing care from an Islamic perspective. The five dimensions are the physical, ethical, moral and ethical, spiritual, and intellectual dimensions of the human being that is related to the core category. The five concepts also have been recognized as antecedent categories, which are the requirements that enable the nurse in maintaining harmony among the five dimensions. Barolia and Karmaliani named these dimensions as five $R s$ : response, reflection, relationship, relatedness, and role modeling. By having the five $R s$, nurses act with caring in the harmony of the five dimensions of caring from the Islamic perspective.

In fact, Barolia and Karmaliani's theory was developed in a general situation. This theory will guide this research to develop a new model of caring practice in the ICU. Differ with other existing theory of caring, Barolia and Karmaliani's theory have one dimension that is not the same with the other theory, which was intellectual dimension. Because, the intellectual dimension in the theory came from the fundamental source of Islam, Quran and Sunna, that does not exist in other theories. Such existing theory of caring more likely result on human science or human relationship.

\section{Caring practice in Islamic Perspectives}

Caring action involves a balance of the hand (skills) and the head (protocol and evidence) with the heart (ethical and human dimension) (Galvin, 2010). Nursing impacts on the health of individuals, families, groups, and populations through caring action, because nurse and patient interaction incorporates a wide range of attitudes and behaviors in the humanistic, relational and clinical domains of nursing practice and constitutes the main vehicles for promoting the quality of nursing care (Cowling, 2000). The caring action in Islam is focused to assist the patient's belief in God (Lovering, 2008, p. 119). Several caring action provided by nurses were as follows:

Table. 3 The Islamic intervention practice can be provided by nurses in Islamic contexts

\begin{tabular}{ll}
\hline Interventions & Explanations \\
\hline $\begin{array}{l}\text { Assess a Spiritual } \\
\text { aspect }\end{array}$ & $\begin{array}{l}\text { Perform an accurate assessment and provide competent and sensitive care. The } \\
\text { nurse must incorporate the patient's religious and spiritual beliefs, as well as } \\
\text { cultural customs (Hyder, 2003). }\end{array}$ \\
\hline
\end{tabular}




\begin{tabular}{ll}
\hline Interventions & Explanations \\
\hline Assist patients to & $\begin{array}{l}\text { Assist the patient's belief in God and articulate the simple words in Islam: } \\
\text { Basmillah (with the name of Allah), Alhamdulillah (acknowledge to Allah), } \\
\text { Astaghfirullah (request forgiveness from Allah) which are always spoken by } \\
\text { Muslim patients for attending the God in their soul (Lovering, 2008). }\end{array}$ \\
& $\begin{array}{l}\text { Perform prayers while the patient is in a seated position or even in a lying } \\
\text { position; 5 times a day. If a patient is unconscious, it is preferred that his or her } \\
\text { face be turned to Mecca (Muslim prayer direction): roughly west-north-west } \\
\text { Perform prayer }\end{array}$ \\
$\begin{array}{l}\text { Comder, 2003) } \\
\text { Perform } \\
\text { communication }\end{array}$ & $\begin{array}{l}\text { Use of specific prayers and verses from the Quran and hadiths for treating pain } \\
\text { (Lovering, 2008). }\end{array}$ \\
Perform "Dua" & $\begin{array}{l}\text { If possible, healthcare should be given by people of the same sex as the patient } \\
\text { (Hyder, 2003). }\end{array}$ \\
Perform a nurse \\
with a same sex \\
$\begin{array}{l}\text { Perform to recite } \\
\text { Quran }\end{array}$
\end{tabular}

\section{Caring Outcomes}

The outcomes of caring were diverse. Caring outcomes can be clinically measured through various instruments. It may also be patient-based, such as information regarding patient satisfaction or health related to quality of life. Caring outcomes may have an economic perspective with measurements that may include length of stay, and cost of testing and treatment.

\section{Table 4. The Empirical Outcomes of Caring and Non-Caring for Patients and Nurses}

\begin{tabular}{ll}
\hline $\begin{array}{l}\text { Empirical outcomes of caring research: } \\
\text { Nurses }\end{array}$ & $\begin{array}{l}\text { Empirical outcomes of caring research: } \\
\text { Patients }\end{array}$ \\
\hline Research outcomes of caring for nurses & Research outcomes of caring for patients \\
& - Emotional-spiritual well-being (dignity, self- \\
- Develop a sense of accomplishment, & control, personhood) \\
satisfaction, purpose, and gratitude & - Enhanced physical healing, lives saved, \\
- Preserved integrity, fulfilment, wholeness, & safety, more energy, less cost, more \\
self-esteem & comfortable, less loss \\
- Live own philosophy & Trust relationship, decrease in alienation, \\
- Develop respect for life and death & feeling closer family relations \\
- Reflective & \\
- Develop love of nursing, increased & \\
knowledge & \\
- Increase coherence of the whole body-mind- & \\
spirit. & \\
\hline
\end{tabular}

Note. Adapted from "Assessing and Measuring caring in Nursing and Health Sciences, " by J. Watson, 2009, p. 17. 


\section{DISCUSSION}

In most clinical theories and models, based on the consideration of human nature, nursing concepts give the fact that in Islamic nursing context, human is regarded as a comprehensive whole, and caring is defined in the holistic framework. The comparison of the viewpoints of Islamic scholars with those of the western scientists with regard to caring, it shows that caring is the axiom of nursing. In addition, in the viewpoints, there is a kind of similarity in presenting services in a health care.

In nursing science, caring is an art, a science, and a philosophy. Caring as a concept is still regarded as differing. Caring is often described as the essence of nursing (Watson, 2008) and is recommended to complement the four metaparadigm concepts of nursing. Caring is an ontology (a way of being), an epistemology (a body of knowledge and way of knowing), an ethic (a moral ideal), an aesthetic (an artful practice), and a sociocultural phenomenon (Ray, 2010). Caring could be a way to define the nurse's practice as caring, and focused on helping others grow (Mayeroff, 1971). Based on Mayeroff, caring had ingredients. The ingredients were knowing, alternating rhythm, patience, honesty, trust, humility, hope and courage. A different view of caring had been looked by Locsin (2005), he viewed caring in nursing technology competencies that existed in the ICU or other room that use technological as a kind of caring. From a knowledge development standpoint, theories of caring and caring knowledge were located within nursing science as well as other disciplines. Caring science has been developing, as a result, caring knowledge and practices affect all health, education, and human service practitioners, in all setting. Consequently, caring science is emerging as a distinct field of study within its own right (Cossette, Pepin, Cote, \& de Courval, 2008; Watson \& Smith, 2002).

Brilowski and Wendler (2004) identified that the concept of caring in Islamic context is embedded in the theological framework of Islam. Caring is a natural outcome of having a love for Allah and the Prophet. Caring in Islam means the will to be responsible, sensitive, concerned with the motivation, and commitment to act in the right order to achieve perfection. In Islam, caring is expressed by three levels: intention, thought, and action. For intention and thought, is understanding of what, when, who to care for and why. At the action level is how and what is related to knowledge, skills, and resources are embedded with the process and outcome of caring (Rassool, 2000). The concept of caring in Islamic context is embedded in the theological framework of Islam. Caring is a natural outcome of having a love for Allah and the Prophet. Caring in Islam means the will to be responsible, sensitive, concerned with the motivation, and commitment to act in the right order to achieve perfection. In Islam, caring is expressed by three levels: intention, thought, and action. For intention and thought is understanding of what, when, who to care for and why. At the action level is how and what is related to knowledge, skills, and resources are embedded with the process and outcome of caring (Rassool, 2000). In order to increase understanding of the concept and to identify its implications for research and practice. Adjunct to the core attribute of caring, the philosopher Mayeroff (1971) described the essential ingredients of caring when a nurse is working. The essential ingredients of caring were knowinga patient, alternating rhythm, patience, honesty, trust, humility, hope and courage. Those attributes were as a cornerstone for a nurse to apply caring for a patient. 
As psycho-socio-cultural-spiritual beings, humans exist in relationship to others and their environment and, to a large extent the universe. Humans exist as individuals, separate from other people, with unique characteristics. Duffy (2009) stated that human beings are differentiated from other forms of life by features such as consciousness, the ability to reason and to move autonomously, and the capacity to use language. Duffy also mentioned that human beings have formal, religious perspectives on life, and this confers respect, dignity, and value for human life.

The caring relationship is a series of interactions between the healer and patient that facilitate healing. Characteristics of this interaction involve empathy, caring, love, warmth, trust, credibility, honesty, expectation, courtesy, respect, and communication (Dossey, 2003, p. A11). According to Janet F Quinn, Smith, Ritenbaugh, Swanson, and Watson (2003), combining elements of caring relationship give a fuller sense of the concepts of those physical, mental, social, and spiritual processes of recovery, repair, renewal, and transformations that increase wholeness. The caring relationship was also stated in all caring theories (see table 1). To grow the caring relationship between the nurse and patient, the nurse definitely needs to have love. The nurse who has loved will create a therapeutic relationship in caring for the patients. Love is essential for human beings. The giving and receiving of love is something that is embedded within everyday nursing and caring practice. Love in the context of nursing is how nurses respond to their emotions, will, and volition (Stickley \& Freshwater, 2002). Hence, the caring relationship is viewed as essential to the healing process of patients.

Caring practice involves a balance of the hand (skills) and the head (protocol and evidence) with the heart (ethical and human dimension) (Galvin, 2010). Many studies revealed about the intervention of caring in many setting and many populations. Nursing impacts on the health of individuals, families, groups, and populations through caring action, because nurse and patient interaction incorporates a wide range of attitudes and behaviors in the humanistic, relational and clinical domains of nursing practice and constitutes the main vehicles for promoting the quality of nursing care (Cowling, 2000). In Islamic context, Muslim patients believe that illness, suffering, and dying is a part of life and could be a test whereby Allah (God) checks the belief of the followers. During illness, Muslims are to seek God's help with patience and prayer, and increase the remembrance of God to obtain peace, ask for forgiveness, give more in charity, and read or listen to more of the Qur'an. God rewards those who bear their suffering with patience and faith in God's mercy. Therefore, seeking help from Allah and praying during the course of illness and difficulties is encouraged.

The empirical outcomes of caring and non-caring for patients and nurses showed that caring was meaningful for the patients, when the nurses were able to show appropriate caring skill. Moreover, caring will result harmony of body, mind, and spirit for nurse and patient. The goal of caring in the context for holistic nursing is healing. Healing is as the emergence of the right relationship between a nurse and a patient. The right relationship between nurse and patient in caring will increase coherence of the whole body-mind-spirit, decrease disorder in the whole body-mind-spirit, maximizes free energy in the whole body-mind-spirit, maximizes freedom, autonomy, and choice in the whole body-mind-spirit, and increases the capacity for creative unfolding of the whole 
body-mind-spirit (Quinn, 2009). Muslim patients may feel more at ease when cared by staff who share similar beliefs as well as other staff who also showed greater understanding and sensitivity to their religious and cultural needs.

Islamic caring in the context of caring is spiritual based care. The patients have the hope, the faith, and the trust. Hope is necessary for future plans. Sources of hope include seeking support, love and stability provided by an important relationship in our life, and putting into action future plans. If the patient believes in God, then hope in God is important. For Muslim this hoping in God is the ultimate source of strength and supersedes all aspirations that are transitional (Narayanasamy, 2004). The patient's hope is closed to their faith. Faith refers to complete trust or confidence in God. Narayanasamy (2004) stated that trust is essential for spiritual health and total wellbeing. Muslim put the trust on God and has strong belief to God will heal them from illness. Nursing is about giving secure to the patients when nurses can establish a trusting relationship with them. A trusting relationship may help patients move towards spiritual wellness. Therefore, nursing concentration on helping patients in their growth can improve patients' overall wellbeing. The primary purposes spiritual based care in Islam to help the person suffering from sickness or disability to attain or maintain peace of mind (Jack, 1986 as cited in Narayanasamy, 2004).

Nursing is caring and caring as healing. It means that caring touched all aspects of human being. As caring in Islamic context focused on spiritual based, caring therefore is as healing for the patients. The spiritual dimensions of individual lives can be significant; spirituality is expressed in a variety of forms and some individuals find that their religion acts as a medium for expressing it. In this respect Muslims who are affected by ill health may find that their spiritual beliefs and practices can be a source of comfort in alleviating their spiritual distress. Muslim spirituality sees a wholeness between the body, mind and spirit, hence Muslims (mostly) believe in the resurrection of the physical body as well as the spirit. This leads to a holistic view of nursing care. Therefore, a sensitive health-care approach that aims to meet the spiritual needs of Muslim patients may go a long way towards helping them to achieve spiritual comfort during the crisis such as illness.

\section{CONCLUSION}

In general, in Islamic nursing, the following is taken into consideration: Caring and nursing are based on well-being improvement and healing, and concentration on all domains of nursing care and the relationship among different dimensions of human (bio-psycho-social-spiritual dimensions). The belief that while being needy, human is powerful and capable of reaching the highest levels of perfection. Paying attention not only to the material world of human but also his or her soul and spirituality dimensions.

Among the features that Islamic scholars consider for human and can be the basis of holistic nursing is that humanity is an accountable creature. Caring is regarded not only as a responsibility and social commitment but also as a holy and altruistic job, benevolence, and among the highest forms of worship. Because it is the caring of a creature that is a reality in a supreme position, which enjoys a divine nature, a heavenly element beautified with God's soul. These statements indicate the importance of Islam's 
humanistic approach toward human in the framework of believing in the reverence for human.

\section{ACKNOWLEDGEMENT}

We would like to extent the acknowledgement to the Directorate of Higher Education (DGHE) who gives us funding to study on this interest topic.

\section{REFERENCES}

Akhtar, S. G. (2002). Nursing with dignity. Part 8: Islam. Retrieved from http://www.nursingtimes.net/nursing-with-dignity-part-8-islam/206284.article

Al-Lahim, S. H. M. (1999). The principles of Islam. Riyadh: The ministry of Islamic affairs, endowments, propagation, and guidance.

Barolia, R., \& Karmaliani, R. (2008). Caring in nursing from an Islamic Perspective: A grounded theory approach. International Journal for Human Caring, 13(1), 5563.

Boykin, A., \& Schoenhofer, S. O. (2001). Nursing as caring. Sudbury, Massachusetts: Jones and Bartlett

Brilowski, G. a., \& Wendler, M. C. (2004). An evolutionary concept analysis of caring. Journal of Advanced Nursing, 50, 641-650.

Cossette, S., Pepin, J., Cote, J. K., \& de Courval, F. P. (2008). The multidimensionality of caring: A confirmatory factor analysis of the Caring Nurse-Patient Interaction Short Scale. Journal of Advanced Nursing, 61(6), 699-710. doi:10.1111/j.13652648.2007.04566.x

Cowling, W. R. (2000). Healing as appreciating wholeness. Advances in Nursing Science, 22(3), 16-32.

Dossey, L. (2003). Samueli conference on definitions and standards in healing research: Working definitions and terms. Alternative Therapies in Health and Medicine, 9(3), A10-12. Retrieved from http://search.proquest.com/docview/204828152?accountid=28431

Duffy, J. R. (2009). Quality caring in nursing : Applying theory to clinical practice, education, and leadership. New York, USA: Springer

Galvin, K. T. (2010). Revisiting caring science: Some integrative ideas for the 'head, hand and heart' of critical care nursing practice. British Association of Critical Care Nurses, 15, 168-175. Retrieved from http://www.ncbi.nlm.nih.gov/pubmed/20626793

Halligan, P. (2006). Caring for patients of Islamic denomination: Critical care nurses' experiences in Saudi Arabia. Journal of Clinical Nursing, 15, 1565-1573.

Hyder, G. (2003). Care of the Muslim patient. Australian Nursing Journal, 11(2), 1-3. Retrieved from http://search.proquest.com/docview/236670819?accountid=28431

Ibrahim, I. A. (1999). A brief illustrated guide to understanding Islam. Retrieved from www. islam-guide.com Retrieved from www. islam-guide.com

Islamic-Life Forums. (2009). Islamic beliefs and six pillars of faith. Retrieved from http://www.islamic-life.com/islamic-beliefs-pillars-faith/article-meaning-beliefallah 
Leininger, M. M. (1988). Caring an essential human need: Proceedings of the three national caring conferences. Detroit, Michigan: Wayne State University.

Locsin, R. C. (2005). Technological competency as caring and the practice of knowing persons as whole. In M. E. Parker (Ed.), Nursing theories and nursing practice (2nd ed., pp. 380-388). Philadelphia: F.A. .

Lovering, S. (2008). Arab Muslim nurses' experiences of the meaning of caring. (Doctoral Doctor of Health Science), The University of Sydney, Sydney: Australia.

Mayeroff, M. (1971). On caring. New York: Harpen Collins Publisher.

Mebrouk, J. (2008). Perception of nursing care: views of Saudi Arabian female nurses. Contemporary Nurse: A Journal for the Australian Nursing Profession, 28(1-2), 149-161. doi:10.5172/conu.673.28.1-2.149

Miklancie, M. A. (2007). Caring for Patients of Diverse Religious Traditions: Islam, a Way of Life for Muslims. Home Healthcare Nurse, 25(6), 413-417.

Moher, D., Shamseer, L., Clarke, M., Ghersi, D., Liberati, A., Petticrew, M., . . Group, P.-P. (2015). Preferred reporting items for systematic review and meta-analysis protocols (PRISMA-P) 2015 statement. 4(1), 1-9. doi:10.1186/2046-4053-4-1

Narayanasamy, A. (2004). The puzzle of spirituality for nursing: a guide to practical assessment. British Journal of Nursing, 13(19), 1140-1144.

Power, C. (2007). Baring our selves. Retrieved from http://www.time.com/time/magazine/article/0,9171,1668236,00.html

Quinn, J. F. (2009). Transpersonal human caring and healing. In B. M. Dossey \& L. Keegan (Eds.), Holistic nursing a handbook for practice (5 ed., pp. 91-99). Sudbury, Massachusetts: Jones and Bartlett.

Quinn, J. F., Smith, M., Ritenbaugh, C., Swanson, K., \& Watson, M. J. (2003). Research guidelines for assessing the impact of the healing relationship in clinical nursing. Alternative Therapies in Health and Medicine, 9(3), 65-79.

Rassool, G. H. (2000). The crescent and Islam: healing, nursing and the spiritual dimension. Some considerations towards an understanding of the Islamic perspectives on caring. Journal of Advanced Nursing, 32(6), 1476-1484. doi:10.1046/j.1365-2648.2000.01614.x

Ray, M. A. (2010). Transcultural caring dynamics in nursing and health care. Philadelphia, PA: F. A. Davis

Stefan, M. (2010). Islamic Beliefs and Practices. New York, NY: Britania Educational.

Stickley, T., \& Freshwater, D. (2002). The art of loving and the therapeutic relationship. Nurs Inq, 9, 250-256.

Watson, J. (2008). Nursing: the philosophy and science of caring (Revision ed.). Boulder, Colorado: The university press of Colorado.

Watson, J., \& Smith, M. C. (2002). Caring science and the science of unitary human beings: A trans-theoretical discourse for nursing knowledge development. Journal of Advanced Nursing, 37, 452-461. 